\title{
Summertime cyclones over the Great Lakes Storm Track from 1860-2100: variability, trends, and association with ozone pollution
}

\author{
A. J. Turner ${ }^{1,2, *}$, A. M. Fiore ${ }^{2, * *}$, L. W. Horowitz ${ }^{2}$, and M. Bauer ${ }^{3}$ \\ ${ }^{1}$ Department of Mechanical Engineering, University of Colorado, Boulder, Colorado, USA \\ ${ }^{2}$ Geophysical Fluid Dynamics Laboratory, NOAA, Princeton, New Jersey, USA \\ ${ }^{3}$ Department of Applied Physics and Applied Mathematics, Columbia University, New York, New York, USA \\ * now at: School of Engineering and Applied Sciences, Harvard University, Cambridge, Massachusetts, USA \\ *** now at: Department of Earth and Environmental Sciences and Lamont-Doherty Earth Observatory of Columbia University, \\ Palisades, New York, USA
}

Correspondence to: A. J. Turner (aturner@fas.harvard.edu)

Received: 8 July 2012 - Published in Atmos. Chem. Phys. Discuss.: 23 August 2012

Revised: 18 December 2012 - Accepted: 7 January 2013 - Published: 16 January 2013

\begin{abstract}
Prior work indicates that the frequency of summertime mid-latitude cyclones tracking across the Great Lakes Storm Track (GLST, bounded by: $70^{\circ} \mathrm{W}, 90^{\circ} \mathrm{W}, 40^{\circ} \mathrm{N}$, and $\left.50^{\circ} \mathrm{N}\right)$ are strongly anticorrelated with ozone $\left(\mathrm{O}_{3}\right)$ pollution episodes over the Northeastern United States (US). We apply the MAP Climatology of Mid-latitude Storminess (MCMS) algorithm to 6-hourly sea level pressure fields from over $2500 \mathrm{yr}$ of simulations with the GFDL CM3 global coupled chemistry-climate model. These simulations include (1) $875 \mathrm{yr}$ with constant 1860 emissions and forcings (Preindustrial Control), (2) five ensemble members for 1860 2005 emissions and forcings (Historical), and (3) future (2006-2100) scenarios following the Representative Concentration Pathways (RCP 4.5 and RCP 8.5) and a sensitivity simulation to isolate the role of climate warming from changes in $\mathrm{O}_{3}$ precursor emissions (RCP $4.5^{*}$ ). The GFDL CM3 Historical simulations capture the mean and variability of summertime cyclones traversing the GLST within the range determined from four reanalysis datasets. Over the 21st century (2006-2100), the frequency of summertime midlatitude cyclones in the GLST decreases under the RCP 8.5 scenario and in the RCP 4.5 ensemble mean. These trends are significant when assessed relative to the variability in the Pre-industrial Control simulation. In addition, the RCP 4.5* scenario enables us to determine the relationship between summertime GLST cyclones and high- $\mathrm{O}_{3}$ events ( $>$ 95th percentile) in the absence of emission changes. The summertime GLST cyclone frequency explains less than $10 \%$ of the
\end{abstract}

variability in high- $\mathrm{O}_{3}$ events over the Northeastern US in the model, implying that other factors play an equally important role in determining high- $\mathrm{O}_{3}$ events.

\section{Introduction}

Climate warming can impact air quality through feedbacks in the chemistry-climate system (e.g. Weaver et al., 2009; Jacob and Winner, 2009; Isaksen et al., 2009; Fiore et al., 2012). For example, mid-latitude cyclones have been shown to impact air quality through their ability to ventilate the boundary layer (e.g. Logan, 1989; Vukovich, 1995; Cooper et al., 2001; Li et al., 2005; Leibensperger et al., 2008; Tai et al., 2012a,b). Surface ozone is an air pollutant of concern to public health (Bernard et al., 2001; Levy et al., 2001) and is particularly important in the Northeastern US where a large fraction of counties have traditionally been out of attainment of the National Ambient Air Quality Standard (NAAQS; EPA, 2006). As such, it is crucial to understand the processes that modulate surface ozone concentrations in this region. Temperature is consistently identified as the most important meteorological variable influencing surface ozone concentrations (Aw and Kleeman, 2003; SanchezCcoyollo et al., 2006; Steiner et al., 2008; Dawson et al., 2007), Jacob and Winner (2009) describe how this temperature dependence can be decomposed into components such as stagnation (Jacob et al., 1993; Olszyna et al., 1997), thermal 
decomposition of peroxyaceytl nitrate (PAN) (Sillman and Samson, 1995), and the temperature dependent emission of isoprene (Guenther et al., 2006; Meleux et al., 2007). In this study we focus explicitly on the stagnation dependence, which is shown to be anticorrelated with changes in midlatitude cyclones (Leibensperger et al., 2008).

Mid-latitude cyclones are, in and of themselves, an important atmospheric process due to their ability to transport energy on the regional scale. As such, there has been major interest in understanding how the mid-latitude cyclone frequency may change in the future (McCabe et al., 2001; Fyfe, 2003; Yin, 2005; Lambert and Fyfe, 2006; Bengtsson et al., 2006; Pinto et al., 2007; Löptien et al., 2007; Ulbrich et al., 2008, 2009; Lang and Waugh, 2011). Most models consistently project a shift in wintertime cyclones in a warming climate (Meehl et al., 2007) but as of now there is no consensus among model predictions as to how summertime cyclone frequencies may change (Lang and Waugh, 2011). Furthermore, because of the synoptic nature of mid-latitude cyclones, there can be substantial interannual and decadal variability in the frequencies. This variability makes it difficult to attribute observed and modeled changes to a particular phenomenon and requires a rigorous analysis of the natural variability. Understanding future changes in summertime cyclone frequencies is a three-step process that first involves characterizing the variability in cyclone frequencies, then evaluating the modeled cyclone frequencies against observational datasets, and finally projecting summertime changes in cyclone frequencies in a warming climate.

Climatological distributions of cyclones are needed to evaluate general circulation model (GCM) cyclone distributions because free-running GCMs (models that are not driven or nudged to observational data) are expected to reproduce the spatial patterns over decadal and centennial time-scales but will differ substantially from observations on a year-toyear basis. Cyclone climatologies have been developed from several methodologies including: visual inspection of NOAA weather maps (e.g. Zishka and Smith, 1980; Leibensperger et al., 2008), automatic detection methods applied to reanalysis datasets (e.g. Zhang and Walsh, 2004; Pinto et al., 2007; Raible et al., 2008), or to GCMs (e.g. Lambert and Fyfe, 2006; Bengtsson et al., 2006; Lang and Waugh, 2011). Raible et al. (2008) and Leibensperger et al. (2008) find generally good agreement between climatologies derived from different methods of cyclone detection.

Leibensperger et al. (2008) found a strong anticorrelation between summertime mid-latitude cyclones and exceedances of the NAAQS ozone threshold (then $84 \mathrm{ppb}$ ) in the Northeastern US as well as a decreasing trend in mid-latitude cyclones over the "southern storm track" which we hereafter refer to as the "Great Lakes Storm Track" (GLST) from 19802006 which they attribute to a warming climate. Building upon their (Leibensperger et al., 2008) work, which focused on the past few decades, we examine the spatial distribution, trends, and variability of mid-latitude cyclones in the Geo- physical Fluid Dynamics Laboratory (GFDL) Climate Model version 3 (CM3) simulations of Pre-industrial, present, and future climate as well as in four reanalyses. We then examine the relationship between summertime mid-latitude cyclones and high- $\mathrm{O}_{3}$ events in future climate projections.

\section{Data and methods}

\subsection{GFDL CM3 model description}

We use a set of simulations conducted with the GFDL CM3 GCM (Donner et al., 2011; Naik et al., 2012; Griffies et al., 2011; Shevliakova et al., 2009). Most pertinent to our application are the fully coupled stratospheric and tropospheric chemistry based on the models of MOZART2 (Horowitz et al., 2003) and AMTRAC (Austin and Wilson, 2003), respectively, and aerosol-cloud interactions in liquid clouds (Ming and Ramaswamy, 2009; Golaz et al., 2011). The GFDL CM3 uses a cubed sphere grid with $48 \times 48$ cells per face, resulting in a native horizontal resolution ranging from $\sim 163 \mathrm{~km}$ to $\sim 231 \mathrm{~km}$ with 48 vertical layers. Results analyzed here have been re-gridded to a traditional latitudelongitude grid with a horizontal resolution of $2^{\circ} \times 2.5^{\circ}$.

Simulations for this study (Table 1) follow the specifications for the Coupled Model Intercomparison Project Phase 5 (CMIP5) in support of the upcoming International Panel on Climate Change (IPCC) Assessment Report 5 (AR5). They are divided into three distinct time periods: (1) control: constant pre-industrial emissions and forcings simulated for $875 \mathrm{yr}$, (2) historical: five model realizations (H1, H2, H3, $\mathrm{H} 4$, and $\mathrm{H} 5$; each ensemble member was initialized from a different year of the control simulation) from 1860 to 2005 with anthropogenic emissions from Lamarque et al. (2010), and (3) future: 2006-2100 for three scenarios: Representative Concentration Pathway (RCP) 8.5 (Riahi et al., 2007, 2011), RCP 4.5 (Clarke et al., 2007; Thomson et al., 2011), and a variation of RCP 4.5 in which only well-mixed green house gases evolve in RCP 4.5 (RCP 4.5*; see also John et al., 2012) and short-lived climate forcers $\left(\mathrm{O}_{3}\right.$ precursors such as $\mathrm{NO}_{\mathrm{x}}, \mathrm{CO}$, NMVOC, as well as aerosols and stratospheric ozone depleting substances) are held at 2005 levels. RCP 8.5 is an extreme warming scenario that corresponds to an average global warming of $4.5 \mathrm{~K}$ below $500 \mathrm{hPa}$ (the lower troposphere) from 2006-2100 in the GFDL GCM. RCP 4.5 is a moderate warming scenario with an average global lower tropospheric warming of $2.3 \mathrm{~K}$ from 2006-2100 in the GFDL GCM. RCP $4.5^{*}$ is, again, a moderate warming scenario but has an average global lower tropospheric warming of $1.4 \mathrm{~K}$ from 2006-2100 in the GFDL GCM, the warming is less pronounced in RCP $4.5^{*}$, compared to RCP 4.5 , because aerosols (dominated by sulfate indirect effect; e.g. John et al., 2012) remain in the atmosphere, sustained by 2005 emission levels. The RCP scenarios are named according to the radiative forcing in the full scenario (e.g. RCP 8.5 for the 
Table 1. Climate and Emission scenarios.

\begin{tabular}{lcllll}
\hline Scenario & Duration & Ensemble Members & Emissions & Warming ${ }^{1}$ & Reference \\
\hline Control & $875 \mathrm{yr}$ & $1(\mathrm{Control})$ & Constant 1860 emissions & & Lamarque et al. (2010) \\
Historical & $1860-2005$ & $5(\mathrm{H} 1, \mathrm{H} 2, \mathrm{H} 3, \mathrm{H} 4, \mathrm{H} 5)$ & Derived historical emissions & & Lamarque et al. (2010) \\
Future & $2006-2100$ & $1(\mathrm{Z1})$ & RCP 8.5 & $4.5 \mathrm{~K}$ & Riahi et al. (2007, 2011) \\
Future & $2006-2100$ & $3(\mathrm{X} 1, \mathrm{X} 3, \mathrm{X} 5)$ & RCP 4.5 & $2.3 \mathrm{~K}$ & Clarke et al. (2007); Thomson et al. (2011) \\
Future & $2006-2100$ & $1\left(\mathrm{X} 3^{*}\right)$ & RCP $4.5^{*}$ & $1.4 \mathrm{~K}$ & John et al. (2012) \\
\hline
\end{tabular}

${ }^{1}$ Change in globally averaged lower troposphere (below $500 \mathrm{hPa}$ ) temperature from 2006-2025 to 2081-2100 (John et al., 2012).

radiative forcing of $8.5 \mathrm{~W} \mathrm{~m}^{-2} \mathrm{~K}^{-1}$ in 2100). It is important to note that, as GFDL CM3 is a free-running chemistry climate model, we do not expect the model to capture individual observed events (as is possible for models driven or nudged to reanalysis meteorology) but we do expect the model to reproduce the climatologies, variability, and trends as observed in the reanalysis datasets.

\subsection{Cyclone detection and tracking methods}

There are many methods of detecting cyclones and storm tracks. Simple schemes that identify the local minima in the daily-average mean sea level pressure (e.g. Lambert et al., 2002; Lang and Waugh, 2011) or use the eddy kinetic energy as a direct representation of storm tracks (Yin, 2005) do not track the storms directly. More advanced algorithms attempt to identify individual storms and track their spatial movement through time (e.g. Murray and Simmonds, 1991; Serreze et al., 1997; Bauer and Del Genio, 2006; Raible et al., 2008; Leibensperger et al., 2008; Hodges et al., 2011; Bauer et al., 2013). Raible et al. (2008) found that three cyclone detection schemes based on substantially different concepts reproduced similar cyclone climatologies but returned different cyclone trends; as such, we deemed it important to utilize a more comprehensive storm tracking algorithm for our trend analysis of storm frequencies.

Here we employ the MAP Climatology of Mid-latitude Storminess (MCMS) cyclone detection and tracking algorithm of Bauer et al. (2013) (http://gcss-dime.giss.nasa.gov/ $\mathrm{mcms} / \mathrm{mcms} . \mathrm{html}$ ); this storm tracker algorithm is an improved version of the MCMS algorithm, originally described by Bauer and Del Genio (2006). The MCMS algorithm is divided into two distinct components: center finding and storm tracking. The center finding portion of the algorithm is devoted to searching a three dimensional (latitude, longitude, and time) sea level pressure (SLP) dataset for local minima. Each potential center is then subjected to a set of filters and thresholds to remove spurious cyclones, specifically, a filter on the local SLP Laplacian such that potential cyclones with a Laplacian of less than $0.3 \mathrm{hPa}{ }^{\circ}{ }^{1} t^{-2}$ are discarded; a topographical filter to prevent spurious detection at high elevations $(>1500 \mathrm{~m}$ ), and a speed filter to limit the maximum cyclone propagation speed to $120 \mathrm{kmh}^{-1}$. Storm centers that meet these criteria are stored and represent an upper bound on the potential set of cyclones in the dataset. The storm tracking component of the algorithm then attempts to build tracks from the set of potential storm centers. Tracks are built using three criteria: (1) the change in SLP will be gradual, (2) cyclones do not quickly change direction, and (3) cyclones generally do not move large distances over a single $6 \mathrm{~h}$ time step so closer centers are preferable; potential centers that optimize these criteria are then stored as storm tracks. We use a filter requiring a storm to travel at least $200 \mathrm{~km}$ over its lifetime, a filter limiting the maximum travel distance to $720 \mathrm{~km}$ over a single time step, and a filter dictating a minimum cyclone lifetime of $24 \mathrm{~h}$. It is also important to note that the position of the storm center from MCMS is determined by a parabolic fit to the local SLP field and is not always at the grid center.

In this work we focus on the storm track (the GLST) along the US-Canada border (between $40^{\circ} \mathrm{N}$ and $50^{\circ}$ ) from Leibensperger et al. (2008) that was originally identified by Zishka and Smith (1980) and Whittaker and Horn (1981) as a major storm track across North America. We focus on the GLST due to its proximity to a large population and the finding of Leibensperger et al. (2008) that the number of storms traversing this track in summer is a predictor of Northeastern US air pollution episodes. Following Leibensperger et al. (2008), we count any storm tracking through the region bounded by $70-90^{\circ} \mathrm{W}$ and $40-50^{\circ} \mathrm{N}$ as part of the GLST, depicted as the gray box in Fig. 1. For comparison with Leibensperger et al. (2008), the duration of the storm in the GLST is not taken into account and the results were found to be insensitive to this assumption.

\subsection{Reanalysis data}

We employ four Sea Level Pressure (SLP) reanalysis datasets for comparison to the GFDL CM3 GCM and to quantify the variability in GLST cyclone frequency. The reanalysis datasets used are: (1) National Center for Environmental Prediction/National Center for Atmospheric Research (NCEP/NCAR) Reanalysis 1 (http://www.cdc.noaa. gov/cdc/data.ncep.reanalysis.html; Kalnay et al., 1996); (2) National Center for Environmental Prediction/Department of Energy (NCEP/DOE) Reanalysis 2 (http://www.cdc. noaa.gov/cdc/data.ncep.reanalysis2.html; Kanamitsu et al., 2002); (3) European Centre for Medium Range Weather 


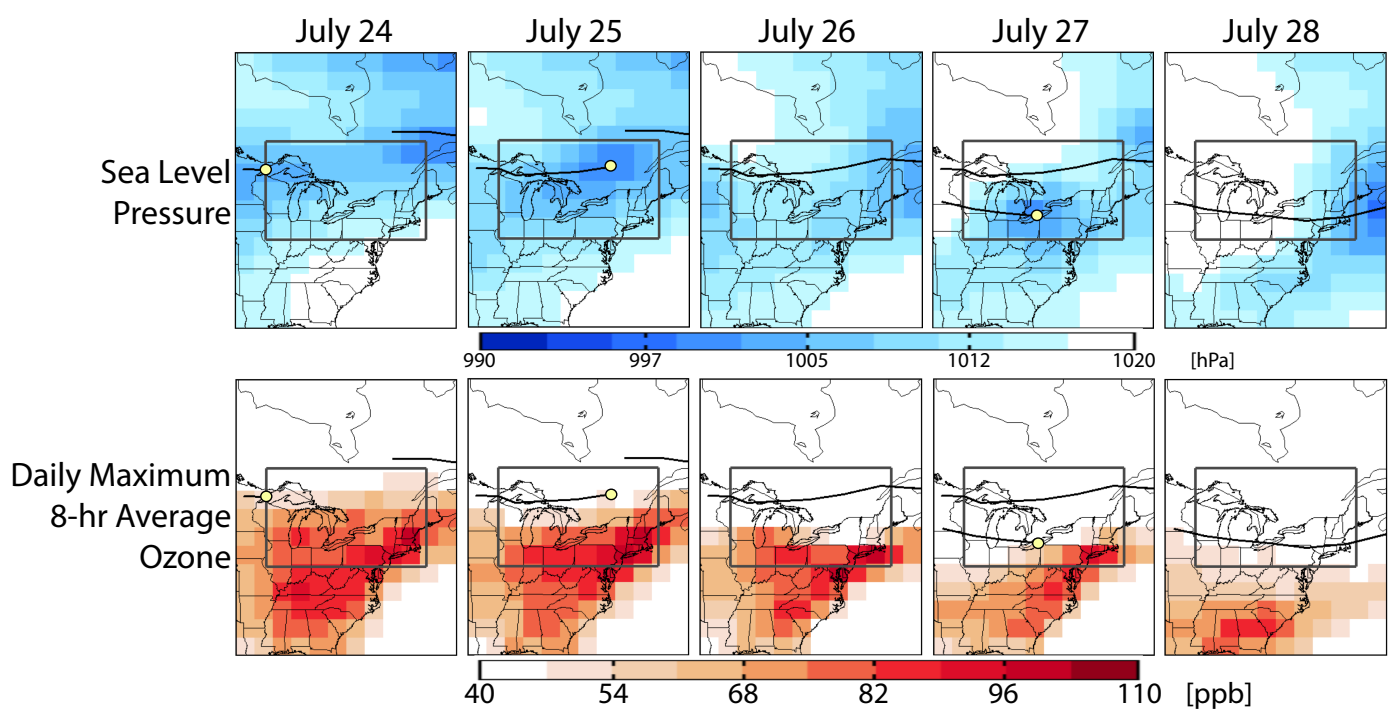

Fig. 1. A clearing event simulated in the GFDL CM3 GCM from 24 July to 28 July for a year selected from the GCM RCP 8.5 simulation. The top row shows the sea level pressure at $9 \mathrm{Z}$ and the bottom row shows the daily maximum 8-h average ozone concentration in surface air. The gray box in all panels indicates the GLST and the black lines are storm track. The yellow dot indicates the position of the storm at the current time step. Storm tracks without a yellow dot are storms that still meet the criteria described in Sect. 2.2 but have moved out of the domain.

Forecasts (ECMWF) Reanalysis (ERA-40) (http://www. ecmwf.int/research/era/do/get/era-40; Uppala et al., 2005); (4) ECMWF ERA-Interim Reanalysis (http://www.ecmwf. int/research/era/do/get/era-interim; Dee et al., 2011). All of the reanalysis datasets have a time resolution of $6 \mathrm{~h}$; a summary of these reanalysis datasets and the time period of data used can be seen in Table 2 .

\section{Cyclone variability and trends in the GLST region}

\subsection{Evaluation of GFDL CM3 over recent decades}

Leibensperger et al. (2008) demonstrated the role of midlatitude cyclones in ventilating ozone during stagnation events by correlating observational ozone data from the EPA's Air Quality System with the NCEP/NCAR Reanalysis 1 dataset. Here we evaluate this process in the GFDL CM3 model. Figure 1 shows a summertime "clearing event" in the model where high surface ozone concentrations occur across the Northeastern US on 24 July, from a selected year of the GCM RCP 8.5 simulation. As a westerly mid-latitude cyclone tracks across the Northeastern US and Southern Canada from 24 July to 26 July, a large reduction in surface ozone $(\sim 30 \mathrm{ppb})$ occurs along the Canadian border region. Another westerly mid-latitude cyclone then tracks across the Great Lakes and Northeastern US from 27 July to 28 July, again associated with a decrease in surface ozone $(\sim 40 \mathrm{ppb})$ over the New England States. From Fig. 1 it appears, at least qualitatively, the GFDL CM3 model captures the surface ozone ventilation resulting from the passage of mid-latitude cyclones.

We then examine the climatological frequency of GLST cyclones in the Historical simulations (see Table 1). Raible et al. (2008) found systematic offsets between mean cyclone frequencies from two reanalysis datasets (ERA-40 and NCEP/NCAR Reanalysis 1). In order to assess the spatial distribution of cyclones across several datasets, we normalize the cyclone frequency to a minimum cyclone frequency of zero and then scale by the maximum cyclone frequency so that the minimum is always zero and the maximum is always unity. This normalization allows the spatial distributions to be easily compared despite offsets in their mean frequency. We compare the variability about the mean frequency with the relative standard deviation (RSD; sometimes referred to as the coefficient of variation), defined as $\sigma / \mu \times 100$ where $\sigma$ is the standard deviation of the number of yearly summertime cyclones and $\mu$ is the mean cyclone frequency.

Normalized summer (JJA) cyclone climatologies for 1958-2005 are generated following Leibensperger et al. (2008), counting all cyclone tracks that pass through $5^{\circ} \times 5^{\circ}$ grid squares, from the GFDL CM3 ensemble mean and NCEP/NCAR Reanalysis 1 SLP fields (Fig. 2a, b, respectively). Figure $2 \mathrm{c}$ shows the difference between these two historical simulation cyclone climatologies. The climatologies both show a prominent northern storm track across the southern tip of the Hudson Bay (Fig. 2a, b). This spatial pattern is consistently found in all of the reanalysis datasets examined (other reanalysis climatologies not shown) and is consistent with those reported in Leibensperger et al. 
(a) Historical (Ensemble Mean): 1958-2005

(b) NCEP/NCAR Reanalysis 1: 1958-2005
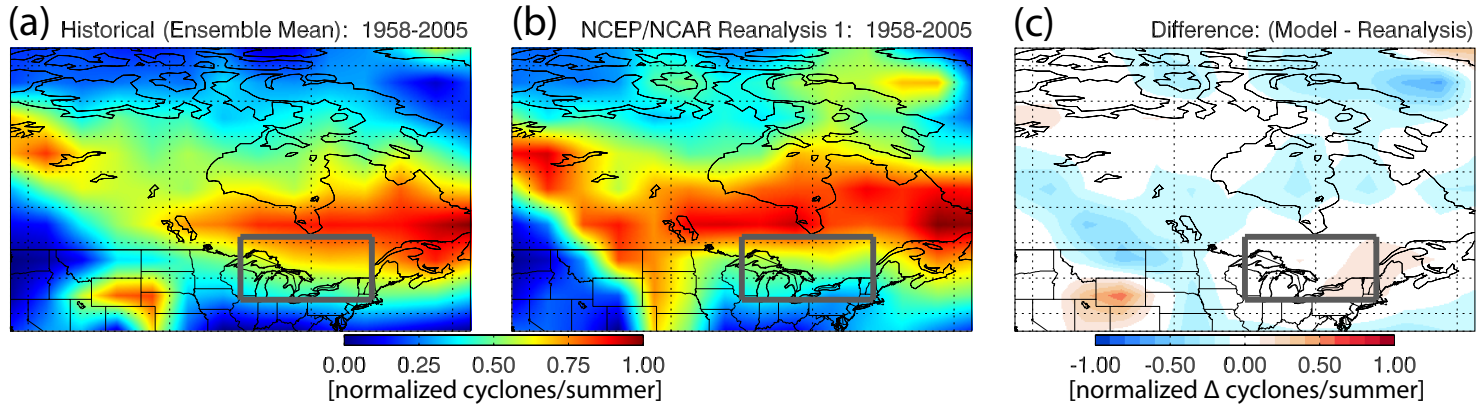

Fig. 2. Spatial distribution of cyclone tracks during summer (JJA) from 1958-2005. Storms are counted per $5^{\circ} \times 5^{\circ}$ box as is done in Leibensperger et al. (2008) and then normalized (data are shifted to a minimum of zero and then scaled by the maximum cyclone frequency) to account for offsets between datasets. (a) GFDL CM3 ensemble mean from the historical runs. (b) NCEP/NCAR Reanalysis 1 climatology. (c) Difference between (a) and (b).

(2008) and Zishka and Smith (1980). The GFDL CM3 model cyclone frequency climatology is within $10 \%$ of the NCEP/NCAR Reanalysis 1 throughout our GLST region of interest (Fig. 2c) providing confidence in its application for a regional analysis of trends and variability. Discrepancies over Alberta and Eastern Canada occur, a region Bauer et al. (2013) identify as problematic where spurious detection could occur due to the topography.

We next examine the variability and trends in the GLST over recent decades. Figure 3 shows the time evolution of cyclone frequencies in the GLST for the reanalysis datasets and the GFDL CM3 Historical ensemble while Table 2 shows the mean $(\mu)$, standard deviation $(\sigma)$, variability (RSD), trend from an ordinary least-squares $(m)$, and the p-value of a trend with a null hypothesis of no trend. We cannot reject the null hypothesis at the $5 \%$ level during the full record length in any of these datasets. We sub-sampled the reanalysis datasets to compare trends over similar time periods, however only the NCEP/NCAR Reanalysis 1 (1980-2006) time period yielded a significant trend. The variability ranges from 19.9$27.7 \%$ with a mean difference of 1.14 cyclones per summer. Figure 3 and Table 2 also highlight the need for normalizing the cyclone frequency when comparing these datasets as there is an offset in cyclone frequency between datasets (as mentioned by Raible et al., 2008). Despite these offsets, the reanalysis datasets do show a strong correlation between each other with a correlation of yearly values $(r)$ ranging from 0.65-1.00 (not shown; ERA-40 and ERA-Interim are fully correlated in the years they overlap), consistent with the finding of Raible et al. (2008).

We reproduce a significant $(p<0.05)$ decreasing trend in cyclones from 1980-2006 in the NCEP/NCAR Reanalysis 1 (see the top panel of inset in Fig. 3) as in Leibensperger et al. (2008). The trend found here, however, is only significant at the $5 \%$ level whereas Leibensperger et al. (2008) report significance at the $1 \%$ level. This discrepancy is attributed to updates in the storm tracker algorithm, as we are using a newer version (Bauer et al., 2013). Additionally, the sta-

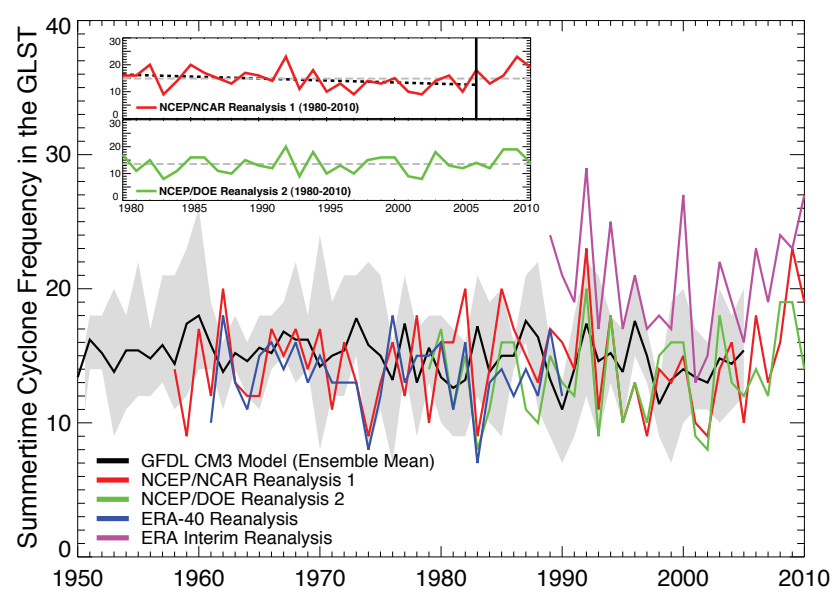

Fig. 3. Summer (JJA) 1950-2010 cyclone frequencies in the GLST as simulated with the GFDL CM3 model Historical ensemble (1860-2005) mean (black), range between the maximum and minimum members (gray shading), NCEP/NCAR Reanalysis 1 (19612010; red), NCEP/DOE Reanalysis 2 (1979-2010; green), ERA-40 Reanalysis (1961-1990; blue), and ERA Interim Reanalysis (19892010; pink). The inset shows 1980-2010 JJA GLST cyclone frequency from NCEP/NCAR Reanalysis 1 (top; red) and NCEP/DOE Reanalysis 2 (bottom; green), the mean cyclone frequency (gray) and significant $(p<0.05)$ trends from an ordinary least-squares regression (black dashed line). A significant decreasing trend occurs only in the NCEP/NCAR Reanalysis 1 cyclone frequency from 1980-2006, the period studied by Leibensperger et al. (2008), but we cannot reject the null hypothesis (zero trend) when the entire 1980-2010 time period is examined or with the NCEP/DOE Reanalysis 2 .

tistical significance of the trend decreases $(p=0.11)$ if we include 2007-2010 as there is a substantial rise in cyclone frequency during these years and we can no longer reject the null hypothesis of no trend; this rise is also seen in the NCEP/DOE Reanalysis 2 dataset (see the bottom panel of inset in Fig. 3). In contrast to Leibensperger et al. (2008), 
Table 2. Data used during the Historical time period (1860-2005). Mean values and standard deviations are in units of cyclones per summer (JJA), trend, p-value of an ordinary least-squares regression, and the variability $(\sigma / \mu \times 100)$ is expressed as a percentage.

\begin{tabular}{|c|c|c|c|c|c|c|}
\hline Dataset & Time Period & $\begin{array}{c}\text { Mean } \\
\mu\end{array}$ & $\begin{array}{c}\text { Standard Deviation } \\
\sigma \sigma\end{array}$ & $\begin{array}{r}\text { Trend } \\
m(p \text {-value })\end{array}$ & $\begin{array}{r}\text { Variability } \\
\text { RSD }\end{array}$ & Reference \\
\hline GFDL CM3 Historical Ensemble Mean & 1980-2005 & 14.45 & 3.41 & $-0.01(p=0.80)$ & $23.6 \%$ & Donner et al. (2011) \\
\hline GFDL CM3 Historical (H1) & 1980-2005 & 14.88 & 3.17 & $0.05(p=0.58)$ & $21.3 \%$ & \\
\hline GFDL CM3 Historical (H2) & 1980-2005 & 14.23 & 3.13 & $-0.07(p=0.42)$ & $22.0 \%$ & \\
\hline GFDL CM3 Historical (H3) & 1980-2005 & 14.69 & 4.07 & $-0.05(p=0.65)$ & $27.7 \%$ & \\
\hline GFDL CM3 Historical (H4) & 1980-2005 & 13.74 & 2.73 & $0.03(p=0.66)$ & $19.9 \%$ & \\
\hline GFDL CM3 Historical (H5) & 1980-2005 & 14.77 & 3.97 & $-0.02(p=0.83)$ & $26.9 \%$ & \\
\hline NCEP/NCAR Reanalysis 1 & $1958-2010$ & 14.49 & 3.52 & $0.02(p=0.56)$ & $24.3 \%$ & Kalnay et al. (1996) \\
\hline NCEP/NCAR Reanalysis 1 & $1980-2006$ & 14.31 & 3.67 & $-0.15(p=0.04)$ & $25.7 \%$ & \\
\hline NCEP/NCAR Reanalysis 1 & 1989-2010 & 14.59 & 4.04 & $0.06(p=0.65)$ & $27.7 \%$ & \\
\hline NCEP/NCAR Reanalysis 1 & $1961-1990$ & 14.67 & 3.07 & $0.05(p=0.43)$ & $20.9 \%$ & \\
\hline NCEP/DOE Reanalysis 2 & $1979-2010$ & 13.56 & 3.37 & $0.05(p=0.42)$ & $24.8 \%$ & Kanamitsu et al. (2002) \\
\hline NCEP/DOE Reanalysis 2 & 1980-2006 & 13.19 & 3.32 & $-0.00(p=0.99)$ & $25.2 \%$ & \\
\hline NCEP/DOE Reanalysis 2 & $1989-2010$ & 13.86 & 3.52 & $0.07(p=0.57)$ & $25.4 \%$ & \\
\hline ERA-40 Reanalysis & $1961-1990$ & 13.50 & 2.60 & $-0.02(p=0.67)$ & $19.2 \%$ & Uppala et al. (2005) \\
\hline ERA-40 Reanalysis & $1964-1990$ & 13.48 & 2.50 & $-0.03(p=0.67)$ & $18.6 \%$ & \\
\hline ERA Interim Reanalysis & $1989-2010$ & 20.59 & 4.28 & $0.01(p=0.93)$ & $20.8 \%$ & Dee et al. (2011) \\
\hline
\end{tabular}

we do not find evidence for climate-driven changes in the Historical GCM simulations or reanalysis storm frequencies over the GLST in recent decades.

\subsection{Natural variability}

We use the $875 \mathrm{yr}$ GFDL CM3 control simulation with constant pre-industrial (1860) emissions and forcings (Table 1) to diagnose the natural variability (internally generated model variability) in migratory cyclones in the GLST during summer. This variability provides a benchmark against which we can assess the significance of trends forced by anthropogenic climate warming over the next century. For continuity with the other simulations analyzed in this study, we define the Pre-industrial Control time period to be from years 1000 to 1860 (though the entire simulation is representative of 1860 conditions).

We begin by subsampling the Control simulation into nine separate $100 \mathrm{yr}$ periods with a five year overlap at the beginning and end of time periods 2-8 (Fig. 4). Figure 4 shows the mean, standard deviation, ordinary least-squares trend, and significance of the trend. The variability $(\sigma / \mu \times 100)$ ranges from $19.7-23.5 \%$, falling within the range in the reanalysis datasets (18.6-27.7\%; see Table 2), with a variability of $21.2 \%$ for the entire Pre-industrial Control time period. Only the 1761-1860 time period shows a statistically significant trend ( $p<0.10$ ), however this is not surprising as a normally distributed dataset would be expected to return one significant trend at the $10 \%$ significance level given 10 samplings. We do not conduct the same analysis to characterize variability in MDA8 ozone events because the distribution in the control simulation is fundamentally different from the present-day distribution due to the absence of anthropogenic emissions.

\subsection{Response to a warming climate in the 21 st century}

Climate change may impact the position of the storm tracks and change the distribution of cyclone frequencies on a regional scale (e.g. Lang and Waugh, 2011). Here we determine the cyclone response to climate warming in the GFDL CM3 model from 2006-2100, under the RCP 8.5, RCP 4.5, and RCP $4.5^{*}$ scenarios (see Table 1 ). In order to assess future changes in the climatology we divide the time period into a base (2006-2025) and a future (2081-2100) period.

Most previous studies of changes in storm tracks have focused on winter, where the peak cyclone frequency occurs off the coast of Nova Scotia (e.g. Lambert and Fyfe, 2006; Lang and Waugh, 2011). For comparison with these studies, we examine the moderate warming climatologies in the RCP 4.5 base and future periods and in the difference (Fig. 5). Figure 5 exhibits a peak cyclone frequency over Nova Scotia consistent with earlier work. We find no change in the geographical position of the storm tracks, but we see a reduction in cyclone frequency from the base period to the future period across the Northeastern US and Southern Canada, with minimal change across Northern Canada (Fig. 5). This general reduction in winter storm tracks is consistent with the findings of Lambert and Fyfe (2006) who show no change in the geographical position of storm tracks, but a reduction in winter storms. Yin (2005) report a poleward shift of the storm tracks on a hemispherically averaged basis; our findings do not necessarily refute the poleward shift reported by Yin (2005) because they examined zonally averaged quantities whereas we focus on a single region. Additionally, 

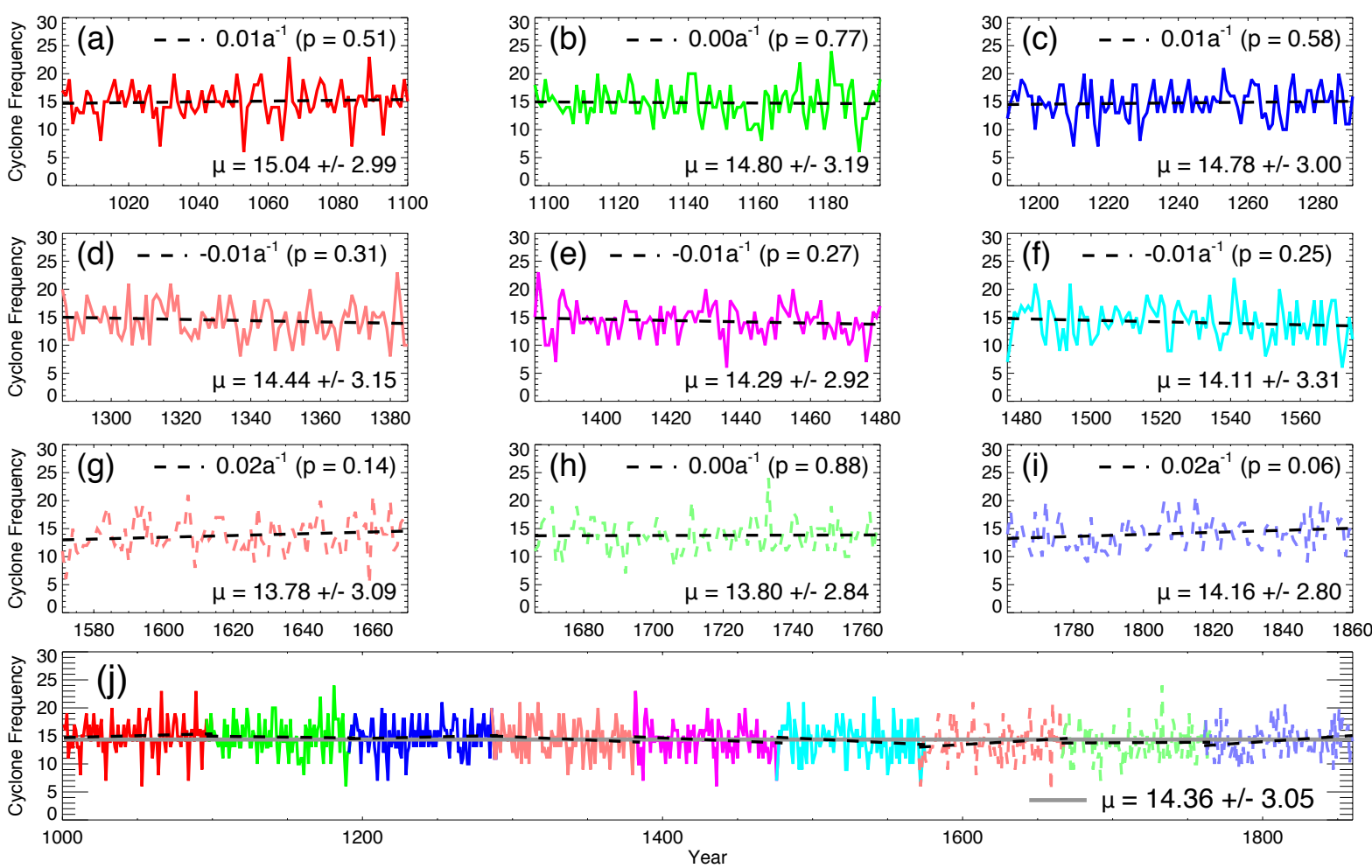

Fig. 4. Summertime (JJA) cyclone frequencies in the GFDL CM3 Pre-industrial Control simulation (perpetual 1860 conditions; Table 1) for selected $100 \mathrm{yr}$ periods. (a) 1001-1100. (b) 1096-1195. (c) 1191-1290. (d) 1286-1385. (e) 1381-1480. (f) 1476-1575. (g) 1571-1670. (h) 1666-1765. (i) 1761-1860. (j) Full control simulation, 1000-1860. The ordinary least squares trend for each time period is overlaid (dashed black line).
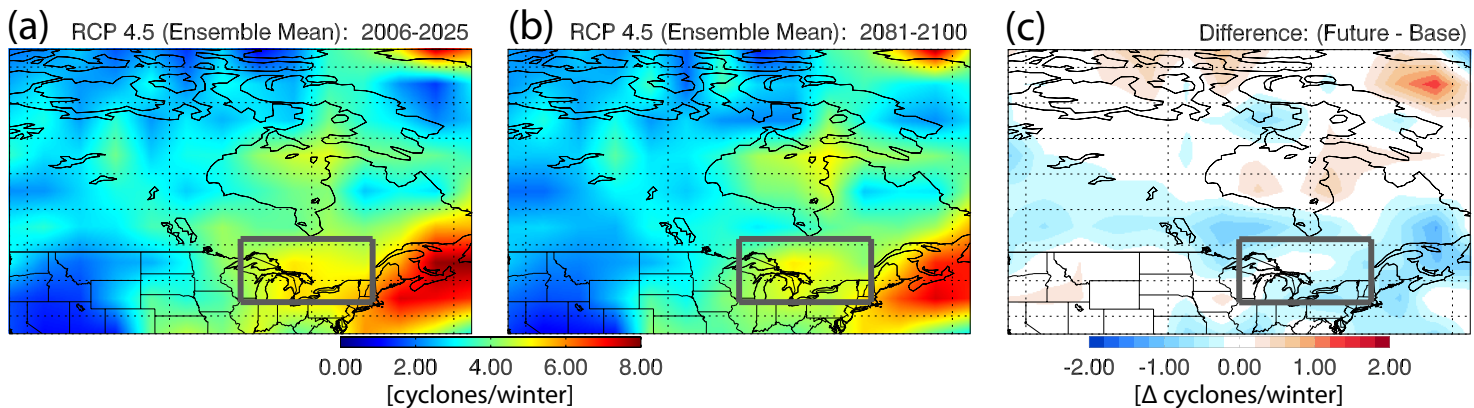

Fig. 5. Spatial distribution of GFDL CM3 cyclone frequencies during winter (DJF) for the RCP 4.5 ensemble mean. (a) Base period: 20062025. (b) Future period: 2081-2100. (c) Difference between (a) and (b). Gray box bounds the GLST.

Fig. 5c indicates a regional reduction in storm frequencies over the mid-latitudes with negligible changes at higher latitudes. This could indicate a shift in storm tracks that is masked by an overall reduction in storms.

We examine next the changes in summertime cyclone climatologies for the 3 future climate warming scenarios (Fig. 6). As in the winter, the geographic distribution of storms does not differ significantly between the base and future periods, however we do see a substantial reduction in storm frequencies across the GLST. This is exemplified in
Fig. 6d where we see a reduction of $\sim 3$ cyclones per summer between the base period and the future period across the mid-latitudes in the RCP 8.5 extreme warming scenario. The high-latitudes experience a minimal reduction (or in some cases even an increase) in cyclone frequency from 2006 to 2100 that could indicate a potential shift in storms from the mid-latitudes to the high-latitudes masked by a general reduction of storm tracks. All of the warming scenarios indicate a reduction in cyclones over the entire GLST region. The similarity of the normalized cyclone frequencies for the 

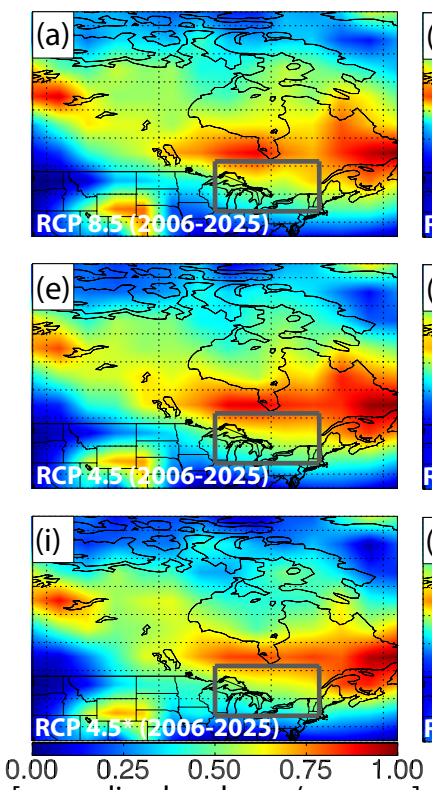

[normalized cyclones/summer]
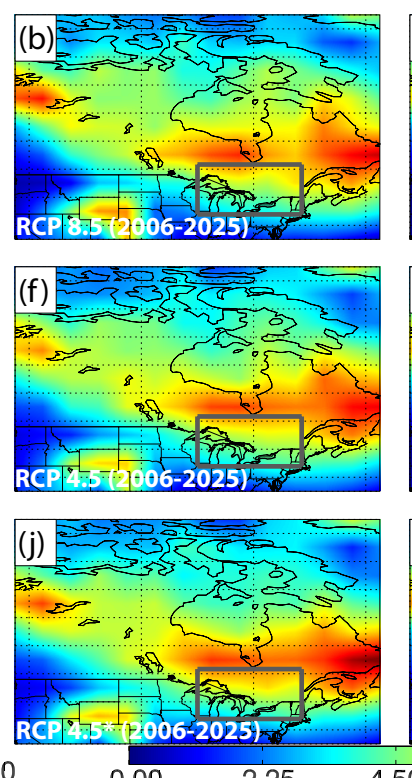

2.25
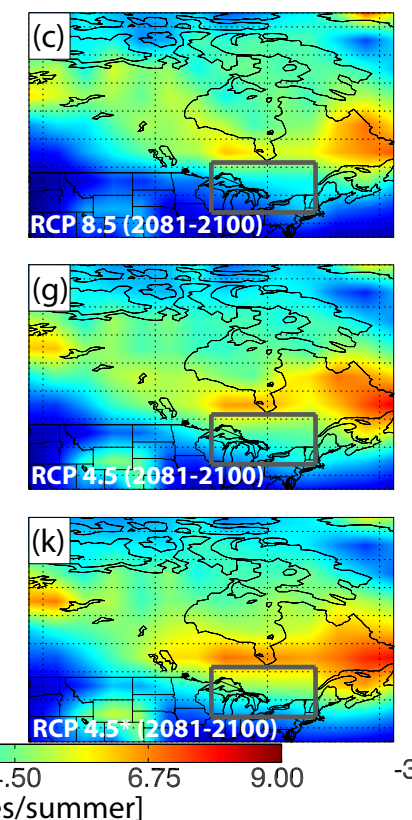
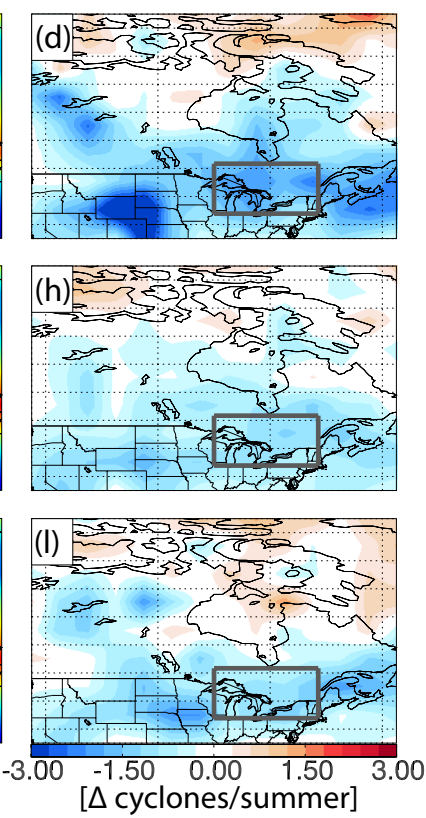

Fig. 6. Spatial distribution of GFDL CM3 cyclone tracks during JJA. Left column (a, e, i) shows the normalized base period (2006-2025), middle left column (b, f, j) shows the base period (2006-2025), middle right column (c, g, k) shows the future period (2081-2100), and the right column $(\mathbf{d}, \mathbf{h}, \mathbf{l})$ is the difference (Future - Base). First row (a, b, $\mathbf{c}, \mathbf{d})$ is the RCP 8.5 scenario, second row (e, $\mathbf{f}, \mathbf{g}, \mathbf{h})$ is RCP 4.5 ensemble mean, and the third row $(\mathbf{i}, \mathbf{j}, \mathbf{k}, \mathbf{l})$ is RCP $4.5^{*}$ (Table 1$)$.

base period in the 3 scenarios (Fig. 6, left column) indicates that the initial conditions are not the major source of the differences in the cyclone distributions by 2100 across the RCP 4.5, RCP 4.5*, and RCP 8.5 scenarios. We conclude from this that the starting conditions do not impact the resulting cyclone distribution in the future period.

Focusing on the GLST, the region of interest for ventilating Northeastern US air pollution in summer (Leibensperger et al., 2008), we find a significant $(p<0.01)$ decreasing trend in cyclones over the $21 \mathrm{st}$ century for two of the RCP 4.5 moderate warming scenario ensemble members; the third member is significant at the $10 \%$ level $(p=0.08)$ (see Fig. 7a). We also find a significant $(p<0.01)$ decreasing trend in cyclones for the RCP 4.5 ensemble mean, with a slope of $-0.03 \mathrm{a}^{-1}$ corresponding to a decrease of $2.85 \mathrm{cy}-$ clones per summer from 2006-2100. Similarly, in the RCP 8.5 extreme warming scenario we find a significant $(p<$ $0.01)$ decreasing $\left(m=-0.06 \mathrm{a}^{-1}\right.$; Fig. $\left.7 \mathrm{~b}\right)$ trend that corresponds to a decrease of 5.70 cyclones per summer from 2006-2100. We also find a narrowing of the distribution of cyclone frequencies from the base to the future period (indicated by the narrowing of the interquartile range) and a reduction in the variability (RSD) for all simulations.

\section{Association of changes in cyclone frequency and high- $\mathrm{O}_{3}$ events over the 21 st century}

High- $\mathrm{O}_{3}$ events are defined to occur when maximum daily 8-h average (MDA8) ozone concentrations exceed a specified threshold. Decreasing cyclone frequencies in the GLST would potentially make the meteorological environment more favorable for high- $\mathrm{O}_{3}$ events by reducing surface ventilation. An obvious threshold choice is $75 \mathrm{ppb}$, the current value for assessing compliance with the US NAAQS for $\mathrm{O}_{3}$. This threshold was recently lowered from $84 \mathrm{ppb}$, the value used in prior work relating GLST storm counts in summer to the number of high- $\mathrm{O}_{3}$ events (Leibensperger et al., 2008). Applying a 75 (or 84) ppb threshold to the RCP 4.5 or RCP 8.5 simulations in the GFDL CM3 is confounded by two factors: (1) the GFDL CM3 model has a high bias in the Northeastern US (see Rasmussen et al., 2012) that makes the occurrence of MDA8 greater than $75 \mathrm{ppb}$ less representative of observed high- $\mathrm{O}_{3}$ events and (2) RCP scenarios include dramatic reductions in $\mathrm{O}_{3}$ precursor emissions (van Vuuren et al., 2011; Lamarque et al., 2011). To account for the second factor, we use the RCP $4.5^{*}$ simulation (Table 1) to examine the impact of changing climate and meteorological conditions on high- $\mathrm{O}_{3}$ events in the absence of changes in emissions of $\mathrm{O}_{3}$ precursors (and other short-lived climate forcing agents). To account for the first factor, we define a model threshold that selects for the high tail of the MDA8 $\mathrm{O}_{3}$ distribution in the Historical simulation (see Table 1). We 


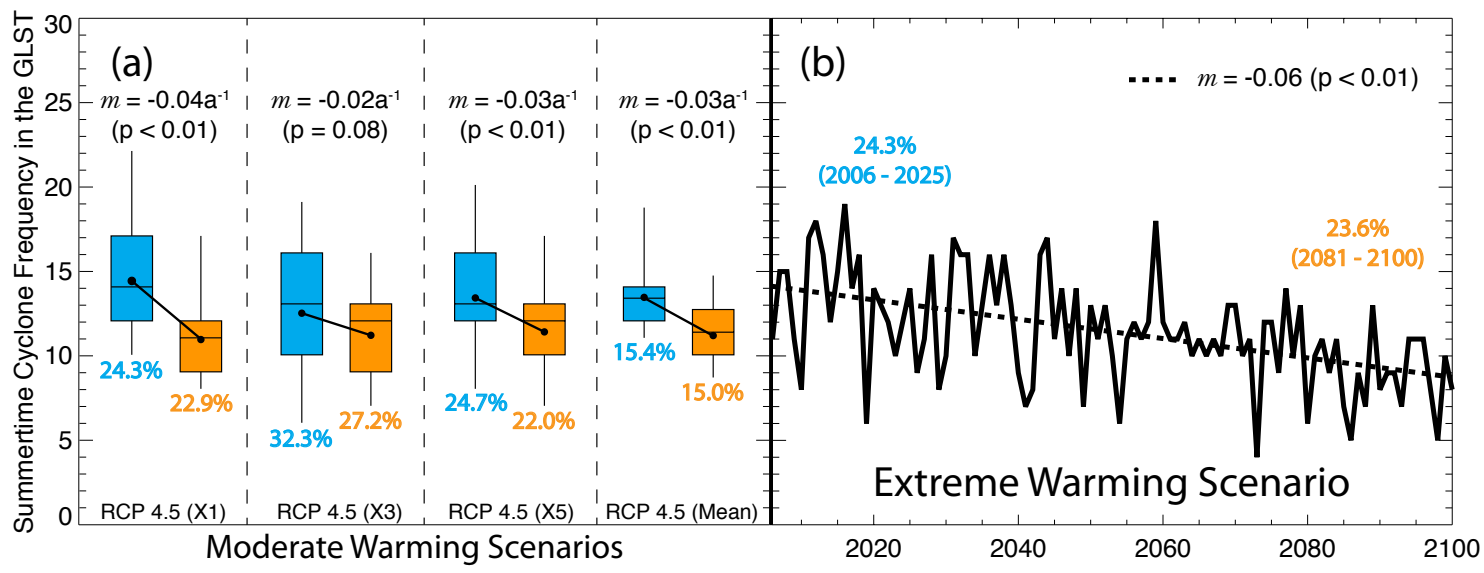

Fig. 7. Change in summer GLST cyclone frequency over the 21st century. (a) Box and whisker plots of the cyclone frequency in the base period (blue; 2006-2025) and future period (orange; 2081-2100). Solid line connects the mean of the base and future period. The slope of the least-squares regression and significance of the slope are shown for each simulation. The variability in the base and future periods are listed below the box and whisker in blue and orange, respectively. (b) Time-series evolution of the summertime GLST cyclone frequency in the RCP 8.5 extreme warming scenario. The significant $(p<0.01)$ least-squares regression is shown as a dashed line with a slope of $-0.06 \mathrm{a}^{-1}$. The variability for the future and base period are listed in blue and orange respectively.

follow the approach of Wu et al. (2008) who highlighted the impact of climate change on the 95th percentile ozone events. We find in the model the value corresponding to the 95th percentile over the last $20 \mathrm{yr}$ (1986-2005) in the Northeastern US (region outlined in black in Fig. 8a) for each member in the Historical scenario and then take the average of these five thresholds, which yields a value of $102 \mathrm{ppb}$. We thus define high- $\mathrm{O}_{3}$ events in the model as MDA8 $\mathrm{O}_{3}$ concentrations greater than $102 \mathrm{ppb}$.

Figure 8 a shows the correlation between high- $\mathrm{O}_{3}$ events in the RCP $4.5^{*}$ and GLST cyclone frequency during summer from 2006-2100. For the majority of the Northeastern US we see an anti-correlation between interannual GLST cyclone frequency and high- $\mathrm{O}_{3}$ events consistent with the findings of Leibensperger et al. (2008) (see their Fig. 7). Figure 8b shows significant $(p<0.01)$ increasing $\left(0.06 \mathrm{a}^{-1}\right)$ and decreasing $\left(-0.03 \mathrm{a}^{-1}\right)$ trends occur over the 21 st century in both Northeastern US high- $\mathrm{O}_{3}$ events and the GLST cyclone frequency, respectively. Again, following Leibensperger et al. (2008), we can remove these trends from both the cyclone and high$\mathrm{O}_{3}$ event frequency to determine the sensitivity of summertime high- $\mathrm{O}_{3}$ events in the Northeastern US over the next century to variability in GLST cyclone frequency. Figure 8c shows a scatterplot of the detrended high- $\mathrm{O}_{3}$ events and cyclone frequency, which yields a sensitivity of $-2.9 \pm 0.3$ high- $\mathrm{O}_{3}$ events per cyclone.

While the sensitivity (slope) found here is similar in magnitude to that found by Leibensperger et al. (2008) $(-4.2$ for 1980-2006 using reanalysis data and observations) the sensitivity is not robust. We find a weak correlation $(r)$ of -0.18 between the detrended GLST cyclone frequency and detrended high- $\mathrm{O}_{3}$ event frequency. In addition to the 95th percentile, we examined thresholds at the 99th per- centile (115 ppb), 90th percentile (95 ppb), and 75th percentile $(84 \mathrm{ppb})$ which yield correlations of $-0.11,-0.24$, and -0.29 , respectively. This weak correlation is thus relatively invariant to the threshold used and never explains more than $10 \%$ of the variance. We further tested whether outliers were skewing our results but find little sensitivity to removing all values when either storm counts or high- $\mathrm{O}_{3}$ events exceed values equal to two standard deviations. We do find periods of strong anti-correlation between the GLST cyclone frequency and high- $\mathrm{O}_{3}$ events on decadal timescales such as 2026-2035 (correlation of -0.79 ) but this relationship does not persist on centennial time-scales.

\section{Conclusions}

We examine the hypothesis of Leibensperger et al. (2008) that a greenhouse warming-driven reduction in summertime migratory cyclones over the Northeastern US and Southern Canada could lead to additional high- $\mathrm{O}_{3}$ days over the populated Northeastern US. Specifically, we investigated trends and variability in the frequency of summertime mid-latitude cyclones tracking across the Great Lakes Storm Track (GLST; bounded by $70^{\circ} \mathrm{W}, 90^{\circ} \mathrm{W}, 40^{\circ} \mathrm{N}$, and $50^{\circ} \mathrm{N}$ ) over the 20th and 21st centuries in the GFDL CM3 chemistry-climate model, and assessed their significance relative to the natural variability in the GLST cyclone frequency in a Pre-industrial Control simulation (Table 1). We find a robust decline in cyclone frequency over the GLST in climate warming scenarios but only a weak association in the model between cyclone frequency and high- $\mathrm{O}_{3}$ events over the next century, and no evidence for climate-driven shifts in recent decades. 

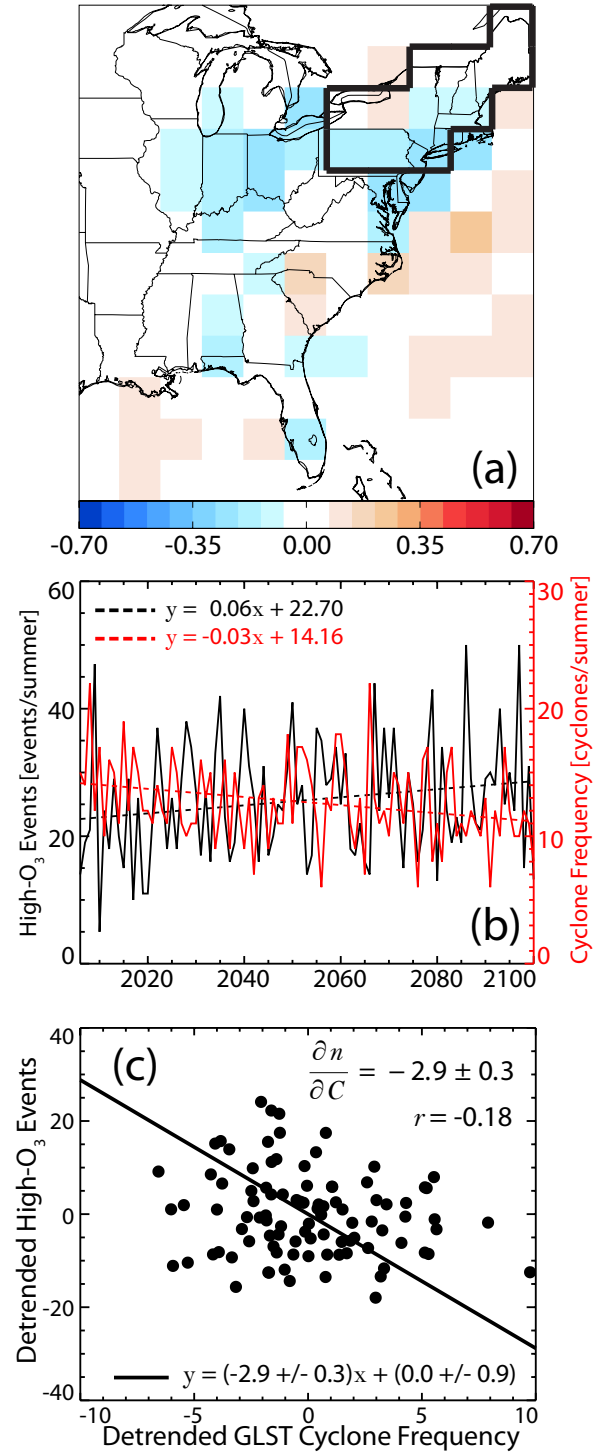

Fig. 8. Long-term trends and correlations between summer (JJA) 2006-2100 GLST cyclone frequency and high- $\mathrm{O}_{3}$ events in the $\mathrm{RCP} 4.5^{*}\left(\mathrm{X}^{*}\right)$ warming scenario in which ozone precursor emissions are held constant at 2005 levels. High- $\mathrm{O}_{3}$ events are defined here as days where the 95th percentile in the 1986-2005 period is exceeded (see Sect. 4 for details). (a) Correlation of the yearly values between the number of high- $\mathrm{O}_{3}$ events and the number of storms tracking through the GLST in summer (JJA); solid black line outlines the grid cells in the Northeastern US. (b) The number of summer (JJA) high-O $\mathrm{O}_{3}$ events in the Northeastern US (black) and GLST cyclone frequency (red) as solid lines with significant trends $(p<0.01)$ from a least-squares regression shown as dashed lines. Equations for significant trends are shown where $x$ as the year subtracted by 2006 (the intercept given is for the year 2006). (c) Scatterplot of high- $\mathrm{O}_{3}$ events $(n)$ and GLST cyclone frequency $(C)$ after removing significant trends shown in panel (b). Solid black line is the reduced major axis regression of the detrended data indicating a sensitivity of $\partial n / \partial C=-2.9 \pm 0.3$ with a correlation $(r)$ of -0.18 .
We apply the MCMS storm tracking tool (Bauer and Del Genio, 2006; Bauer et al., 2013) to locate and track cyclones in the GFDL CM3 6-hourly sea level pressure fields. The GFDL CM3 model represents Northeastern US cyclone clearing events (Fig. 1) and falls within the range of climatologies generated from four reanalysis datasets (Table 2; mean values of 14.92 in GFDL CM3 and 13.50-20.59 in the reanalyses, with variabilities of $21.3 \%$ and $19.3-24.9 \%$, respectively, for the full record length). This agreement lends confidence to applying the GFDL CM3 model to future projections under warming climate scenarios. While we reproduce a significant $(p<0.05)$ decreasing trend in the NCEP/NCAR Reanalysis 1 summertime GLST cyclone frequency from 1980-2006 this trend was no longer found to be statistically significant at the $5 \%$ level when we expanded the analysis period to 2010 (inset of Fig. 3). We did not find a significant trend in any of the other reanalysis products.

Significant $(p<0.01)$ decreasing trends in summertime GLST cyclone frequency were found in each climate warming scenario; the largest reduction in cyclone frequency occurred in the extreme warming scenario (RCP 8.5) with a slope of $-0.06 \mathrm{a}^{-1}$ corresponding to a reduction of $5.70 \mathrm{cy}$ clones per summer from 2006 to 2100 . These trends are significant when measured against internally generated model variability in the $875 \mathrm{yr}$ Pre-industrial Control simulation (Sect. 3.2). While robust to the noise of the Pre-industrial Control simulation, uncertainty remains as to whether these trends would occur in other GCMs. For example, Lang and Waugh (2011) found disagreement between CMIP3 models in changes in summertime cyclone frequency; the previous generation GFDL climate model version 2.1 (CM2.1) generally projects fewer future cyclones (zonally averaged) than the multi-model mean. Lang and Waugh (2011), however, used a simple cyclone detection scheme (identifying local minima in the daily mean sea level pressure field) due to the limited availability of data from the CMIP3 models, which represents an upper bound on the set of cyclones as it may identify thermal lows or systems with a lifetime less than one day.

We find that the GLST summer cyclone frequency is weakly anti-correlated with high- $\mathrm{O}_{3}$ events across the Northeastern US in a moderate warming scenario in the absence of $\mathrm{O}_{3}$ precursor emission changes (RCP $4.5^{*}$, Table 1 ). In this scenario, cyclones are projected to decrease with a slope of $-0.03 \mathrm{a}^{-1}$ and high- $\mathrm{O}_{3}$ events increase with a slope of $0.06 \mathrm{a}^{-1}$ over the 21 st century (Fig. 8). By removing the trend from the high- $\mathrm{O}_{3}$ events and cyclone frequency we find that the sensitivity of high- $\mathrm{O}_{3}$ events in the Northeastern US with respect to variability in GLST cyclone frequency is $-2.9 \pm 0.3$, consistent with the -4.2 of Leibensperger et al. (2008). The sensitivity derived from the GFDL CM3 model, however, is not robust and never explains more than $10 \%$ of the variability. 
Although we find no strong evidence of cyclone frequency explaining the variability of high- $\mathrm{O}_{3}$ events, recent work by Barnes and Fiore (2012) suggests that the jet position in the model explains a substantial portion of surface ozone variability over the Eastern United States. Further investigation of the relationship between ozone variability (including the incidence of high- $\mathrm{O}_{3}$ events and storm counts) and their connection to jet position is warranted. Additionally, future efforts should determine whether the regional summertime cyclone decrease, found here, is robust among other CMIP5 GCMs or observational data of longer record length. This work demonstrates the ability of a chemistry-climate model to capture the mean and variability of storm frequency suggesting these tools should yield insights when applied to process-oriented analysis for quantifying feedbacks in the coupled chemistry-climate system. Our findings highlight the need for careful study before applying relationships derived in present day conditions to future climate even in the absence of emission changes.

Acknowledgements. This work was supported by the NOAA Ernest F. Hollings Scholarship Program (AJT), the Environmental Protection Agency (EPA) Science To Achieve Results (STAR) grant 83520601 (AMF), and the NASA Applied Sciences Program grant NNX09AN77G (AJT). The contents of this article are solely the responsibility of the grantee and do not necessarily represent the official view of the EPA. Further, the EPA does not endorse the purchase of any commercial products or services mentioned in the publication. NCEP/NCAR Reanalysis 1 and NCEP/DOE Reanalysis 2 data provided by the NOAA/OAR/ESRL PSD, Boulder, Colorado, USA, from their web site at http://www.esrl.noaa.gov/psd/. Special thanks also to ECMWF for providing ERA-Interim and ERA-40 data. We are grateful to Vishali Naik for her assistance with the CMIP5 simulations. We also thank Frank Indiviglio for his assistance with the GFDL computing system, Eric Leibensperger, Andrew Wittenberg, and Jacob Oberman for their comments on early results, as well as Harald Rieder, Elizabeth Barnes, Daniel Jacob, and Daven Henze for their valuable comments on this manuscript.

Edited by: B. N. Duncan

\section{References}

Austin, J. and Wilson, R. J.: Ensemble simulations of the decline and recovery of stratospheric ozone, J. Geophys. Res., 111, D16314, doi:10.1029/2005JD006907, 2003.

Aw, J. and Kleeman, M. J.: Evaluating the first-order effect of intraannual temperature variability on urban air pollution, J. Geophys. Res., 108, 4365, doi:10.1029/2002JD002688, 2003.

Barnes, E. A. and Fiore, A. M.: Surface ozone variability and its response to climate change: Key role for jet position, available at: http://fallmeeting.agu.org/2012/eposters/eposter/a53d-0171/, AGU Fall Meeting, San Francisco, USA, 2012.
Bauer, M. and Del Genio, A. D.: Composite analysis of winter cyclones in a GCM: influence on climatological humidity, J. Climate, 19, 1652-1672, 2006.

Bauer, M., Tselioudis, G., and Rossow, W.: A new climatology for investigating storm influences on the extratropics, J. Appl. Meteorol., in review, 2013.

Bengtsson, L., Hodges, K. I., and Roeckner, E.: Storm tracks and climate change, J. Climate, 19, 3518-3543, 2006.

Bernard, S. M., Samet, J. M., Grambsch, A., Ebi, K. L., and Romieu, I.: The potential impacts of climate variability and change on air pollution-related health effects in the United States, Environ. Health Persp., 109, 199-209, 2001.

Clarke, L., Edmonds, J., Jacoby, H., Pitcher, H., Reilly, J., and Richels, R.: Scenarios of Greenhouse Gas Emissions and Atmospheric Concentrations. Sub-report 2.1A of Synthesis and Assessment Product 2.1 by the US Climate Change Science Program and the Subcommittee on Global Change Research, Tech. rep., Department of Energy, Office of Biological \& Environmental Research, Washington, DC, 2007.

Cooper, O. R., Moody, J. L., Parrish, D. D., Trainer, M., Ryerson, T. B., Holloway, J. S., Hübler, G., Fehsenfeld, F. C., Oltmans, S. J., and Evans, M. J.: Trace gas signatures of the airstreams within North Atlantic cyclones: case studies from the North Atlantic Regional Experiment (NARE '97) aircraft intensive, J. Geophys. Res., 106, 5437-5456, doi:10.1029/2000JD900574, 2001.

Dawson, J. P., Adams, P. J., and Pandis, S. N.: Sensitivity of PM 2.5 to climate in the Eastern ES: a modeling case study, Atmos. Environ., 41, 1494-1511, 2007.

Dee, D. P., Uppala, S. M., Simmons, A. J., Berrisford, P., Poli, P., Kobayashi, S., Andrae, U., Balmaseda, M. A., Balsamo, G., Bauer, P., Bechtold, P., Beljaars, A. C. M., van de Berg, L., Bidlot, J., Bormann, N., Delsol, C., Dragani, R., Fuentes, M., Geer, A. J., Haimberger, L., Healy, S. B., Hersbach, H., Hólm, E. V., Isaksen, L., Kållberg, P., Köhler, M., Matricardi, M., McNally, A. P., Monge-Sanz, B. M., Morcrette, J.-J., Park, B.K., Peubey, C., de Rosnay, P., Tavolato, C., Thépaut, J.-N., and Vitart, F.: The ERA-Interim reanalysis: configuration and performance of the data assimilation system, Q. J. Roy. Meteor. Soc., 137, 553-597, doi:10.1002/qj.828, 2011.

Donner, L. J., Wyman, B. L., Hemler, R. S., Horowitz, L. W., Ming, Y., Zhao, M., Golaz, J.-C., Ginoux, P., Lin, S. J., Schwarzkopf, M. D., Austin, J., Alaka, G., Cooke, W. F., Delworth, T. L., Freidenreich, S. M., Gordon, C. T., Griffies, S. M., Held, I. M., Hurlin, W. J., Klein, S. A., Knutson, T. R., Langenhorst, A. R., Lee, H.-C., Lin, Y., Magi, B. I., Malyshev, S. L., Milly, P. C. D., Naik, V., Nath, M. J., Pincus, R., Ploshay, J. J., Ramaswamy, V., Seman, C. J., Shevliakova, E., Sirutis, J. J., Stern, W. F., Stouffer, R. J., Wilson, R. J., Winton, M., Wittenberg, A. T., and Zeng, F.: The dynamical core, physical parameterizations, and basic simulation characteristics of the atmospheric component AM3 of the GFDL Global Coupled Model CM3, J. Climate, 24, 3484-3519, doi:10.1175/2011JCLI3955.1, 2011.

EPA, US: Air Quality Criteria for Ozone and Related Photochemical Oxidants, Tech. rep., US Environmental Protection Agency, Washington, DC, 2006.

Fiore, A. M., Naik, V., Spracklen, D. V., Steiner, A., Unger, N., Prather, M., Bergmann, D., Cameron-Smith, P. J., Cionni, I., 
Collins, W. J., Dalsøren, S., Eyring, V., Folberth, G. A., Ginoux, P., Horowitz, L. W., Josse, B., Lamarque, J.-F., MacKenzie, I. A., Nagashim, T., O`Connor, F. M., Righi, M., Rumbold, S., Shindell, D. T., Skeie, R. B., Sudo, K., Szopa, S., Takemura, T., and Zeng, G.: Global Air Quality and Climate, Chemical Society Reviews, 41, 6663-6683, 2012.

Fyfe, J. C.: Extratropical Southern Hemisphere cyclones: Harbingers of climate change?, J. Climate, 16, 2802-2805, 2003

Golaz, J.-C., Salzmann, M., Donner, L. J., Horowitz, L. W., Ming, Y., and Zhao, M.: Sensitivity of the aerosol indirect effect to subgrid variability in the cloud parameterization of the GFDL Atmosphere General Circulation Model AM3, J. Climate, 24, 3145-3160, doi:10.1175/2010JCLI3945.1, 2011.

Griffies, S. M., Winton, M., Donner, L. J., Horowitz, L. W., Downes, S. M., Farneti, R., Gnanadesikan, A., Hurlin, W. J., Lee, H. C., Liang, Z., Palter, J. B., Samuels, B. L., Wittenberg, A. T., Wyman, B., Yin, J., and Zadeh, N.: The GFDL CM3 Coupled Climate Model: characteristics of the ocean and sea ice simulations, J. Climate, 24, 3520-3544, doi:10.1175/2011JCLI3964.1, 2011.

Guenther, A., Karl, T., Harley, P., Wiedinmyer, C., Palmer, P. I., and Geron, C.: Estimates of global terrestrial isoprene emissions using MEGAN (Model of Emissions of Gases and Aerosols from Nature), Atmos. Chem. Phys., 6, 3181-3210, doi:10.5194/acp-63181-2006, 2006.

Hodges, K. I., Lee, R. W., and Bengtsson, L.: A comparison of extratropical cyclones in recent reanalyses ERA-Interim, NASA MERRA, NCEP CFSR, and JRA-25, J. Climate, 24, 4888-4906, 2011.

Horowitz, L. W., Walters, S., Mauzerall, D. L., Emmons, L. K., Rasch, P. J., Grainer, C., Tie, X., Lamarque, J. F., Schultz, M. G., Tyndall, G. S., Orlando, J. J., and Brasseur, G. P.: A global simulation of tropospheric ozone and related tracers: Description and evaluation of MOZART, version 2, J. Geophys. Res., 108, 4784, doi:10.1029/2002JD002853, 2003.

Isaksen, I., Granier, C., Myhre, G., Berntsen, T., Dalsøren, S., Gauss, M., Klimont, Z., Benestad, R., Bousquet, P., Collins, W., Cox, T., Eyring, V., Fowler, D., Fuzzi, S., Jöckel, P., Laj, P., Lohmann, U., Maione, M., Monks, P., Prevot, A., Raes, F., Richter, A., Rognerud, B., Schulz, M., Shindell, D., Stevenson, D., Storelvmo, T., Wang, W.-C., van Weele, M., Wild, M., and Wuebbles, D.: Atmospheric composition change: climate-chemistry interactions, Atmos. Environ., 43, 5138-5192, doi:10.1016/j.atmosenv.2009.08.003, 2009.

Jacob, D. J. and Winner, D. A.: Effect of climate change on air quality, Atmos. Environ., 43, 51-63, 2009.

Jacob, D. J., Logan, J. A., Gardner, G. M., Yevich, R. M., Spivakovsky, C. M., Wofsy, S. C., Sillman, S., and Prather, M. J.: Factors regulating ozone over the United States and its export to the global atmosphere, J. Geophys. Res., 98, 14817-14826, 1993.

John, J. G., Fiore, A. M., Naik, V., Horowitz, L. W., and Dunne, J. P.: Climate versus emission drivers of methane lifetime from 1860-2100, Atmos. Chem. Phys. Discuss., 12, 18067-18105, doi:10.5194/acpd-12-18067-2012, 2012.

Kalnay, E., Kanamitsu, M., Collins, W., Deaven, D., Gandin, L., Iredell, M., Saha, S., White, G., Woollen, J., Zhu, Y., Chelliah, M., Ebisuzaki, W., Higgins, W., Janowiak, J., Mo, K. C.,
Ropelewski, C., Wang, J., Leetmaa, A., Reynolds, R., Jenne, R., and Joseph, D.: The NCEP/NCAR 40-year reanalysis project, B. Am. Meteorol. Soc., 77, 437-471, 1996.

Kanamitsu, M., Ebisuzaki, W., Woollen, J., Yang, S. K., Hnilo, J. J., Fiorino, M., and Potter, G. L.: NCEP-DOE AMIP-II reanalysis (R-2), B. Am. Meteorol. Soc., 83, 1631-1643, 2002.

Lamarque, J.-F., Bond, T. C., Eyring, V., Granier, C., Heil, A., Klimont, Z., Lee, D., Liousse, C., Mieville, A., Owen, B., Schultz, M. G., Shindell, D., Smith, S. J., Stehfest, E., Van Aardenne, J., Cooper, O. R., Kainuma, M., Mahowald, N., McConnell, J. R., Naik, V., Riahi, K., and van Vuuren, D. P.: Historical (1850-2000) gridded anthropogenic and biomass burning emissions of reactive gases and aerosols: methodology and application, Atmos. Chem. Phys., 10, 7017-7039, doi:10.5194/acp10-7017-2010, 2010.

Lamarque, J.-F., Kyle, G. P., Meinshausen, M., Riahi, K., Smith, S. J., van Vuuren, D. P., Conley, A. J., and Vitt, F.: Global and regional evolution of short-lived radiatively-active gases and aerosools in the Representative Concentration Pathways, Climatic Change, 109, 191-212, doi:10.1007/s10584-011-0155-0, 2011.

Lambert, S. J. and Fyfe, J. C.: Changes in winter cyclone frequencies and strengths simulated in enhanced greenhouse warming experiments: results from the models participating in the IPCC diagnostic exercise, Clim. Dynam., 26, 713-728, doi:10.1007/s00382-006-0110-3, 2006.

Lambert, S., Sheng, J., and Boyle, J.: Winter cyclone frequencies in thirteen models participating in the Atmospheric Model Intercomparison Project (AMIP1), Clim. Dynam., 19, 1-16, doi:10.1007/s00382-001-0206-8, 2002.

Lang, C. and Waugh, D. W.: Impact of climate change on the frequency of Northern Hemisphere summer cyclones, J. Geophys Res., 116, D04103, doi:10.1029/2010JD014300, 2011.

Leibensperger, E. M., Mickley, L. J., and Jacob, D. J.: Sensitivity of US air quality to mid-latitude cyclone frequency and implications of 1980-2006 climate change, Atmos. Chem. Phys., 8, 7075-7086, doi:10.5194/acp-8-7075-2008, 2008.

Levy, J. I., Carrothers, T. J., Tuomisto, J. T., Hammitt, J. K., and Evans, J. S.: Assessing the public health benefits of reduced ozone concentrations, Environ. Health Persp., 109, 1215-1226, 2001.

Li, Q. B., Jacob, D. J., Park, R., Wang, Y. X., Heald, C. L., Hudman, R., Yantosca, R. M., Martin, R. V., and Evans, M.: North American pollution outflow and the trapping of convectively lifted pollution by upper-level anticyclone, J. Geophys. Res., 110, D04103, doi:10.1029/2004JD005039, 2005.

Logan, J. A.: Ozone in rural areas of the United States, J. Geophys. Res., 94, 8511-8532, 1989.

Löptien, U., Zolina, O., Gulev, S., Latif, M., and Soloviov, V.: Cyclone life cycle characteristics over the Northern Hemisphere in coupled GCMs, Clim. Dynam., 31, 507-532, 2007.

McCabe, G. J., Clark, M. P., and Serreze, M.: Trends in Northern Hemisphere surface cyclone frequency and intensity, J. Climate, 14, 2763-2768, 2001.

Meehl, G. A., Stocker, T. F., Collins, W. D., Friedlingstein, P., Gaye, A. T., Gregory, J. M., Kitoh, A., Knutti, R., Murphy, J. M., Noda, A., Raper, S. C. B., Watterson, I. G., Weaver, A. J., and Zhao, Z.-C.: Global Climate Projections, in: Climate Change 2007: The Physical Science Basis. Contribution of Working 
Group I to the Fourth Assessment Report of the Intergovernmental Panel on Climate Change, Tech. rep., Cambridge University Press, Cambridge, UK and New York, NY, USA, 2007.

Meleux, F., Solomon, F., and Giorgi, F.: Increase in summer European ozone amounts due to climate change, Atmos. Environ., 41, 7577-7587, 2007.

Ming, Y. and Ramaswamy, V.: Nonlinear climate and hydrological responses to aerosol effects, J. Climate, 22, 1329-1339, doi:10.1175/2008JCLI2362.1, 2009.

Naik, R.J. and Simmonds, I.: A numerical scheme for tracking cyclone centres from digital data. Part I: Development and operation of the scheme, Aust. Meteorol. Mag., 39, 155-166, 2012.

Naik, V., Horowitz, L. W., Fiore, A. M., Ginoux, P., Mao, J., Aghedo, A., and Levy II, H.: Preindustrial to present day changes in short-lived pollutant emissions on atmospheric composition and climate forcing, J. Geophys. Res., in review, 2013.

Olszyna, K. J., Luria, M., and Meagher, J. F.: The correlation of temperature and rural ozone levels in Southeastern USA, Atmos. Environ., 31, 3011-3022, 1997.

Pinto, J. G., Ulbrich, U., Leckebusch, G. C., Spangehl, T., Reyers, M., and Zacharias, S.: Changes in storm track and cyclone activity in three SRES ensemble experiments with the ECHAM5/MPI-OM1 GCM, Clim. Dynam., 29, 195-210, doi:10.1007/s00382-007-0230-4, 2007.

Raible, C. C., Della-Marta, P. M., Schwierz, C., Wernli, H., and Blender, R.: Northern Hemisphere extratropical cyclones: a comparison of detection and tracking methods and different reanalyses, Mon. Weather Rev., 136, 880-897, doi:10.1175/2007MWR2143.1, 2008.

Rasmussen, D. J., Fiore, A. M., Naik, V., Horowitz, L. W., McGinnis, S. J., and Schultz, M. G.: Surface ozone-temperature relationships in the Eastern US: a monthly climatology for evaluating chemistry-climate models, Atmos. Environ., 47, 142-153, 2012.

Riahi, K., Gröbler, A., and Nakicenovic, N.: Scenarios of longterm socio-economic and environmental development under climate stabilization, Technol. Forecast. Soc., 74, 887-935, doi:10.1016/j.techfore.2006.05.026, 2007.

Riahi, K., Rao, S., Krey, V., Cho, C., Chirkov, V., Fischer, G., Kindermann, G., Nakicenovic, N., and Rafaj, P.: A scenario of comparatively high greenhouse gas emissions, Climatic Change, 109, 33-57, doi:10.1007/s10584-011-0149-y, 2011.

Sanchez-Ccoyollo, O. R., Ynoue, R. Y., Martins, L. D., and Andradede, M. de F.: Impacts of ozone precursor limitation and meteorological variables on ozone concentrations in Sao Paulo, Brazil, Atmos. Environ., 40, S552-S562, 2006.

Serreze, M. C., Carse, F., Barry, R. G., and Rogers, J. C.: Icelandic low cyclone activity: Climatological features, linkages with the $\mathrm{NAO}$, and relationships with recent changes in the northern hemisphere circulation, J. Climate, 10, 453-464, 1997.

Shevliakova, E., Pacala, S. W., Hurtt, S. M. G. C., Milly, P. C. D., Caspersen, J. P., Sentman, L. T., Fisk, J. P., Wirth, C., and Crevoisier, C.: Carbon cycling under 300 years of land use change: importance of the secondary vegetation sink, Global Biogeochem. Cy., 23, GB2022, doi:10.1029/2007GB003176, 2009.

Sillman, S. and Samson, P. J.: Impact of temperature on oxidant photochemistry in urban, polluted rural and remote environments, J. Geophys. Res., 100, 11497-11508, 1995.
Steiner, A. L., Tonse, S., Cohen, R. C., Goldstein, A. H., and Harley, R. A.: Influence of future climate and emissions on regional air quality in California, J. Geophys. Res., 111, D18303, doi:10.1029/2005JD006935, 2008.

Tai, A. P. K., Mickley, L. J., Jacob, D. J., Leibensperger, E. M., Zhang, L., Fisher, J. A., and Pye, H. O. T.: Meteorological modes of variability for fine particulate matter $\left(\mathrm{PM}_{2.5}\right)$ air quality in the United States: implications for $\mathrm{PM}_{2.5}$ sensitivity to climate change, Atmos. Chem. Phys., 12, 3131-3145, doi:10.5194/acp12-3131-2012, 2012a.

Tai, A. P. K., Mickley, L. J., and Jacob, D. J.: Impact of 2000-2050 climate change on fine particulate matter $\left(\mathrm{PM}_{2.5}\right)$ air quality inferred from a multi-model analysis of meteorological modes, Atmos. Chem. Phys., 12, 11329-11337, doi:10.5194/acp-1211329-2012, 2012 b.

Thomson, A. M., Calvin, K. V., Smith, S. J., Kyle, G. P., Volke, A., Patel, P., Delgao-Arias, S., Bond-Lamberty, B., Wise, M. A., Clarke, L. E., and Edmonds, J. A.: RCP4.5: a pathway for stabilization of radiative forcing by 2100 , Climatic Change, 109 , 77-94, doi:10.1007/s10584-011-0151-4, 2011.

Ulbrich, U., Pinto, J. G., Kupfer, H., Leckebusch, G. C., Spangehl, T., and Reyers, M.: Changing Northern Hemisphere storm tracks in an ensemble of IPCC climate change simulations, Theor. Appl. Climatol., 96, 117-131, 2008.

Ulbrich, U., Leckebusch, G. C., and Pinto, J. G.: Extra-tropical cyclones in the present and future climate: a review, J. Climate, 21, 1669-1679, 2009.

Uppala, S. M., Kållberg, P. W., Simmons, A. J., Andrae, U., Bechtold, V. D. C., Fiorino, M., Gibson, J. K., Haseler, J., Hernandez, A., Kelly, G. A., Li, X., Onogi, K., Saarinen, S., Sokka, N., Allan, R. P., Andersson, E., Arpe, K., Balmaseda, M. A., Beljaars, A. C. M., Berg, L. V. D., Bidlot, J., Bormann, N., Caires, S., Chevallier, F., Dethof, A., Dragosavac, M., Fisher, M., Fuentes, M., Hagemann, S., Hólm, E., Hoskins, B. J., Isaksen, L., Janssen, P. A. E. M., Jenne, R., Mcnally, A. P., Mahfouf, J.F., Morcrette, J.-J., Rayner, N. A., Saunders, R. W., Simon, P., Sterl, A., Trenberth, K. E., Untch, A., Vasiljevic, D., Viterbo, P., and Woollen, J.: The ERA-40 re-analysis, Q. J. Roy. Meteor. Soc., 131, 2961-3012, doi:10.1256/qj.04.176, 2005.

van Vuuren, D. P., Edmonds, J. A., Kainuma, M., Riahi, K., Thomson, A. M., Hibbard, K., Hurtt, G. C., Kram, T., Krey, V., Lamarque, J.-F., Masui, T., Nakicenovic, M. M. N., Smith, S. J., and Rose, S.: The representative concentration pathways: an overview, Climatic Change, 109, 5-31, doi:10.1007/s10584-0110148-z, 2011.

Vukovich, F. M.: Regional-scale boundary layer ozone variations in the Eastern United States and their association with meteorological variations, Atmos. Environ., 29, 2259-2273, 1995.

Weaver, C., Liang, X.-Z., Zhu, J., Adams, P., Amar, P., Avise, J., Caughey, M., Chen, J., Cohen, R., Cooter, E., Dawson, J., Gilliam, R., Gilliland, A., Goldstein, A., Grambsch, A., Grano, D., Guenther, A., Gustafson, W., Harley, R., He, S., Hemming, B., Hogrefe, C., Huang, H.-C., Hunt, S., Jacob, D., Kinney, P., Kunkel, K., Lamarque, J.-F., Lamb, B., Larkin, N., Leung, L., Liao, K.-J., Lin, J.-T., Lynn, B., Manomaiphiboon, K., Mass, C., McKenzie, D., Mickley, L., O`Neill, S., Nolte, C., Pandis, S., Racherla, P., Rosenzweig, C., Russell, A., Salathé, E., Steiner, A., Tagaris, E., Tao, Z., Tonse, S., Wiedinmyer, C., Williams, A., Winner, D., Woo, J.-H., Wu, S., and Wuebbles, D.: 
A preliminary synthesis of modeled climate change impacts on US regional ozone concentrations, B. Am. Meteorol. Soc., 90, 1843-1863, doi:10.1175/2009BAMS2568.1, 2009.

Whittaker, L. M. and Horn, L. H.: Geographical and seasonal distribution of North American cyclogenesis, Mon. Weather Rev., 109, 2312-2322, 1981.

Wu, S., Mickley, L. J., Leibensperger, E. M., Jacob, D. J., Rind, D., and Streets, D. G.: Effects of 2000-2050 global change on ozone air quality in the United States, J. Geophys. Res., 113, L18701, doi:10.1029/2007JD008917, 2008.
Yin, J. H.: A consistent poleward shift of the storm tracks in simulations of 21st century climate, Geophys. Res. Lett., 32, 23002317, doi:10.1029/2005GL023684, 2005.

Zhang, X. and Walsh, J. E.: Climatology and interannual variability of arctic cyclone activity: 1948-2002, J. Climate, 17, 2300-2317, 2004.

Zishka, K. M. and Smith, P. J.: The climatology of cyclones and anticyclones over North America and surrounding ocean environs for January and July, 1950-77, Mon. Weather Rev., 108, 387401, 1980. 